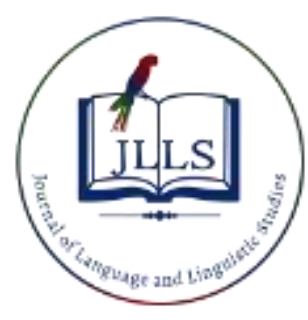

Available online at www.jlls.org

JOURNAL OF LANGUAGE AND LINGUISTIC STUDIES

ISSN: $1305-578 \mathrm{X}$

Journal of Language and Linguistic Studies, 16(2), 1084-1095; 2020

\title{
The attitudes of professional translators and translation students towards computer-assisted translation tools in Yemen
}

\author{
Othman Saleh Mahdy Mohammed 1a (D), Shaikh Suhel Samad ${ }^{b}$ (D) Hassan Saleh Mahdi \\ ${ }^{a}$ Dr. Babasaheb Ambedkar Marathwada University, Aurangabad, India \\ ${ }^{b}$ Dr. Babasaheb Ambedkar Marathwada University, Aurangabad, India \\ ${ }^{b}$ Balqarn, University of Bisha, Saudi Arabia
}

APA Citation:

Mohammed, S, M, M., \& Samad, S, S., and Mahdi, H, S (2020). The Attitudes of Professional Translators and Translation Students towards Computer-Assisted Translation Tools in Yemen. Journal of Language and Linguistic Studies, 16(2), 1084-1095.

Submission Date:23/04/2020

Acceptance Date:30/05/2020

\begin{abstract}
The translation industry has witnessed rapid technological improvements in recent years. This rapid improvement is ascribed to a huge demand for the workload. Using a computer in the field of translation is very important due to the huge demand for fast and accurate translation. Translation tools came to existence due to the low proficiency of machine translation. CAT tools have become essential for many institutions, companies, and organizations. CAT tools increase productivity and minimize translation costs. The purpose of this study is to scrutinise the attitudes of professional translators and translation students towards CAT tools in Yemen. The questionnaire of this study was composed of 27 statements distributed to four constructs. The link of the questionnaire was distributed via WhatsApp to the participants. The other tool was an online interview about some issues related to CAT tools. These responses were analysed qualitatively. The researchers distributed the questionnaire to 250 people, and the valid responses of the participants were 56. The analysis shows that they have positive attitudes towards CAT tools. The results of the study show that professional translators and translation students show a positive attitude. Unexpectedly, the profiles of the participants do not play any role in their attitudes towards CAT tools.
\end{abstract}

(C) 2020 JLLS and the Authors - Published by JLLS.

Keywords: Attitudes; translation; professional translators; CAT tools; students; Yemen

\section{Introduction}

The era of industrialization, globalization, and the rapid growth of interaction between countries all over the world forced nations to interact with each other. This interaction has increased the demand for translation services. Translators face work pressure and they looked for solutions. One of these solutions is using Computer-assisted translation (CAT) tools. CAT tools have gained their importance due to their accurate outcome (for more details see Mohammed, Samad \& Mahdi 2018). Almost all companies and organizations seek for the translators who are qualified in using these tools. CAT tools always are used

*Corresponding author. Tel.: +919175585134

E-mail address: othmanwosabi924@gmail.com 
to facilitate and accelerate the process of translation. These tools are beneficial for both translators and clients. They save translators' times and they also reduce the price of the translation. Nowadays most translation companies and organizations integrate CAT tools. In the field of education, universities adapted and included such new courses that related to CAT tools in their curricula to qualify their graduates with recent trends in CAT tools to find suitable jobs. A job seeker for translation must have a good command of handling CAT tools.

Despite the advantages and the benefits that CAT tools offer, they still suffer from shortcomings. For example, they are expensive, especially for users from low-income countries like Yemen. The in-service translator believes that $\mathrm{s} / \mathrm{he}$ will have to invest a considerable amount of money to obtain software and the way of using it. The new translator also needs to refer to the brochure or seek technical support from the expert for facilitating the difficulties that s/he may encounter.

The perception of using CAT tools has been investigated by many studies (e.g. Alotaibi, 2014; Gough, 2011; Mahfouz, 2018). These studies explored the factors that may affect the integration of CAT tools in translation. However, most of these were conducted in countries in which people have high or enough income. Thus, this study aims at investigating the attitudes of professional translators and translation students towards CAT tools in Yemen (a country with low income).

\subsection{Literature review}

\subsubsection{Computer-assisted translation}

Technology plays a crucial role in the translation field and it affects heavily the process of translation. Despite this great effect, the implementation of CAT tools is still not up to the expectations. Unfortunately, the researchers observed that departments of translation in Yemeni universities do not pay much more attention to CAT tools. Based on the syllabuses at Yemeni universities, one can notice that translation courses that are allotted to teach using technology in translation, in general, and CAT tools, in particular, are still insufficient. For example, in some Yemeni universities, the translation departments assign only two courses related to technology and translation. Yet, the problem exists even if the universities and institutes include such courses into the curriculum. The way of teaching of CAT tools is still unsolved; the teachers who teach these courses are not well qualified in teaching these tools (Al-Jarf, 2017).

Another problem for the implementation of CAT tools is due to the financial restrictions to purchase CAT tools. Universities and institutes should try their best to overcome these restrictions and limitations by offering suitable training programs, which meet the demand of the current translation markets. Gümüş (2014) cited in Mahfouz (2018) states that "employment in each professional context has specific requirements, which requires training translators for a global market with diverse technological requirements"(p.154). This indicates that the programs cannot cover all the aspects of CAT tool training requirements. Ajzen (2005, p. 241) finds out that attitude can be considered as "an individual disposition to respond favourably or unfavourably to an object, person, institution or event, or any other discriminable aspect of the individual's world".

Many studies dealt with translators' attitudes to CAT tools, such as (Mahfouz, 2018; Alotaibi, 2014; and Gough, 2011). They investigated translators' perceptions of CAT tools and their implementations. For instance, Gough (2011) investigated awareness and perception of the new open, collaborative tools and processes and the degree of tools usage and process of participation. Her study concluded that the translators' awareness, perception, and use of tools are determined by their attitude towards adopting new technologies. Formal education and training do not play a fundamental issue in implementing CAT tools. Similarly, Bundgaard (2017) addresses the attitudes of translators towards Translator-Computer Interaction in the form of MT-assisted TM translation. Her study shows that the translators expressed a 
negative attitude towards MT in many respects, but also acknowledged positive aspects of the technology and expect MT to play a significant role in their future working lives. The translators showed neither positive nor negative attitude toward TM which might indicate that TM may be integrated into their tasks of translation. The translators seem to have a flexible and pragmatic attitude towards translator-computer interaction, adopting CAT tools despite their inadequacies.

The students' attitudes towards CAT tools may be changed after they are given a course on these tools, to evaluate this assumption; Çetiner (2018) conducted a study. He used a pre-and post-test design. He found that there were statistically significant differences between pre-and post-test scores. This result indicated that students had a positive attitude if CAT tools were taught and introduced to the translation courses. The students realized the benefits and advantages of using CAT tools such as quality assurance function, aligning text for translation memory.

In the UK, Dillon and Fraser (2006) explored the attitudes of UK-based professional translators towards TM in their works. Found that translators who used CAT tools had more positive attitudes towards CAT tools. The translators with strong IT skills were more likely to have positive perceptions of CAT tools. The study found that younger translators had a positive general perception of TM irrespective of actual use. The study suggested that the non-adoption of CAT tools had more to do with translators' lack of understanding of and familiarity with CAT tools rather than the nature of applications of CAT tools. In opposition to the positive attitudes that were shown by some studies, Bundgaard (2017) addressed the attitudes of translators towards Translator-Computer Interaction in the form of MTassisted TM translation. Her study showed that the translators expressed neither positive nor negative attitude toward TM which might indicate that TM may be integrated into their tasks of translation. The translators seem to have a flexible and pragmatic attitude towards translator-computer interaction, adopting CAT tools despite their inadequacies.

\subsubsection{CAT tools in the Arab World}

Based on the knowledge of the authors, very limited studies investigated the use of CAT tools in general and very less dealt with attitudes of translators to CAT tools in the Arab countries. The less focus on this field may be ascribed to the recent introduction of these tools to the Arab market, and their apparent high costs which make organizations and educational institutes and universities refrain from purchasing these tools. Alotaibi (2014) dealt with teaching CAT tools to students of translation; at the College of Languages and Translation, King Saud University, Riyadh. Her study aimed at assessing the students' degree of knowledge regarding CAT tools and their expectations and attitudes towards using these tools. She found that at the beginning of the course students had very poor and confused knowledge about the use of technology in translation. However, they showed a positive attitude to cope with a new field of knowledge. They demonstrated high levels of motivation to learn and were keen to apply the skills they acquired in course to other translation courses. The study highlights the need to teach students both the potentials and the limitations of technology to have a reasonable expectation concerning CAT tools. The recent Arabic study that dealt with exploring the attitudes of Egyptian translation students and professionals towards CAT tools with specific reference to their ease of use, perceived benefits, and compatibility was conducted by Mahfouz's (2018). The results of this study found that a positive attitude among translators towards using CAT tools. She found that translators with better computer skills had more positive attitudes towards CAT tools.

\subsection{Research questions}

The study tries to answer the following research questions:

1. Do Yemeni translators and translation students have a positive attitude toward CAT tools and are enthusiastic to implement CAT tools? 
2. Do Yemeni professional translators and translation students who have good knowledge of computer skills have more positive attitudes towards CAT tools than those who do not have good knowledge of computer skills?

\section{Method}

This study uses a mixed-method of both quantitative and qualitative data. The quantitative data was gathered by conducting a questionnaire.

\subsection{Instrument(s)}

The questionnaire consisted of two parts: the first part was allotted to demographic data, which included age, current job, years of experience, qualification, the use of the computer, types of the translated text and CAT tool(s) used. The second part was allotted to the statements that were adopted from the instrument developed by Moore and Benbasat (1991) and Mahfouz (2018) to investigate the attitudes of translator students and professional translators in Yemen to CAT tools. Moore and Benbasat (1991) instrument consisted of 34 statements distributed on eight constructs. For this study, only four constructs were selected. Some statements were taken from either Moore and Benbasat (1991) or Mahfouz (2018) and adapted to suit the purpose of the current study. The qualitative data was a short electronic interview. In this regard, the researchers asked some open-ended questions to some participants randomly, Via Whatsapp. They asked about the reasons for not implementing and using CAT tools, and also the benefits of CAT tools in translation. The design of the questionnaire is shown in Table 1.

Table 1. Summary of study constructs and number of questionnaire statements

\begin{tabular}{ccc}
\hline Construct/section & Number of Statements & Statements modified \\
\hline Benefits & 10 & None \\
Ease of use & 7 & None \\
Image & 3 & 2 \\
Compatibility & 7 & None \\
Total & 27 & 2 \\
\hline
\end{tabular}

In addition to the above six demographic questions, the questionnaire ended up with 28 statements that aimed to cover four main constructs. A 5-point Likert scale was used. The participants had to choose one of the five possible responses that were ranged from Strongly Agree to Strongly Disagree. The neutral category was included for users who might be neutral about any of the statements. The questionnaire was evaluated by five professors in translation departments to ensure the validity and reliability of the items. Based on the evaluation of these professors, some statements were modified. The questionnaire was designed using Google Forms and then distributed online to the participants via email and WhatsApp. The total responses were 56 participants. The reliability of the questionnaire is shown in Table 2.

Table 2. Test reliability scores

\begin{tabular}{lr}
\hline N of Items & Cronbach's Alpha \\
\hline 27 & .896 \\
\hline
\end{tabular}


The questionnaire was distributed on 15 January till 6 February 2020. Fifty-six responses were received. The sample of the study is small because the questionnaire restricted its goal to only the users of CAT tools in Yemen.

\subsection{Participants}

The participants in the current study were either professional translators or translation students in Yemen. All the professional translators hold at least B.A in English and some courses in translation or a relevant field. They were supposed to have such experience with using some CAT tools. On the other hand, the students of translation were chosen from the fourth year Translation Department, the University of Science of Technology, Yemen. This means that they had studied several courses in translation in general as well as some courses related to translation technology in particular.

\section{Results}

The data analysis was divided into two sections. The first section discusses the demographic information of the participants while the second section deals with participants' responses to the four constructs.

\subsection{Participant's demographics information}

The first section in the questionnaire was assigned to elicit the demographic information of the participants. Their demographic information is shown in Table 3.

Table 3. Participant's demographics information

\begin{tabular}{cccc}
\hline \multirow{2}{*}{ Age } & 20-30 years, & $\mathrm{N}$ & $\%$ \\
& 31 to 40 years & 16 & 28.6 \\
Jobs & More than 40 years. & 28 & 50.0 \\
& Translators & 12 & 21.4 \\
Experience & Students & 35 & 62.5 \\
& From one to five years, & 21 & 37.5 \\
Computer skills & from six to ten years & 24 & 42.9 \\
& Still students. & 23 & 41.1 \\
Texts translated & Excellent & 9 & 16.1 \\
& very good & 17 & 30.4 \\
CAT tool used & Good & 32 & 57.1 \\
& translate general texts & 7 & 12.5 \\
& translate financial texts, and & 52 & $92 \%$ \\
& Translate other types of text. & 2 & $3.2 \%$ \\
& use SDL Trados & 2 & $3.2 \%$ \\
& use MemoQ, & 9 & $16 \%$ \\
& Use OmegaT & 3 & $5.4 \%$ \\
& Use Matecat & 1 & $1.8 \%$ \\
& use other CAT tools & 3 & $5.4 \%$ \\
& & 40 & $71.4 \%$ \\
\hline
\end{tabular}

Table 3 shows that about half of the participants were between 31 to 40 years. In terms of job, the majority of the participants were professional translators $62.5 \%$. Regarding the experience, $42.9 \%$ of the respondents had one to five years of experience, and $41.1 \%$ of the respondents had six to ten years of experience. Only $16.1 \%$ of the respondents had no experience because they were still students. Regarding computer skills, $57.1 \%$ of the respondents reported to have very good skills in computer. 


\subsection{The benefit of CAT tools}

The following table consists of ten statements; these statements investigate the benefit of using CAT tools.

Table 4. The benefit of CAT tools.

\begin{tabular}{lcccccc}
\hline $\mathrm{N}$ & Statements & $\mathrm{SD}$ & $\mathrm{D}$ & $\mathrm{N}$ & $\mathrm{A}$ & $\mathrm{SA}$ \\
\cline { 2 - 7 } 1 & & 5.4 & 3.6 & 10.7 & 42.9 & 37.5 \\
2 & Using CAT tools improves the quality of my translation & 1.8 & 12.5 & 17.9 & 39.3 & 28.6 \\
3 & CAT tools increase my productivity. & 3.6 & 3.6 & 5.4 & 55.4 & 32.1 \\
4 & I work faster when using CAT tools. & 1.8 & 00 & 7.1 & 41.1 & 50.0 \\
5 & The advantages of CAT tools are far more than the & 3.6 & 5.4 & 17.9 & 53.6 & 19.6 \\
$\quad$ disadvantages. & & & & & \\
6 & The benefit of using CAT tools are apparent to me & 3.6 & 5.4 & 16.1 & 57.1 & 17.9 \\
7 & I would lose my work if I could not work with CAT tools. & 7.1 & 50.0 & 30.4 & 8.9 & 3.6 \\
8 & Translators who use CAT tools get more work in my area than & 3.6 & 16.1 & 30.4 & 35.7 & 14.3 \\
$\quad$ those who do not. & & & & \\
9 & It is more difficult to become established as a translator if you & 5.4 & 32.1 & 19.6 & 35.7 & 7.1 \\
& are not familiar with CAT tools & & & & & \\
1 & Translators who use CAT tools have high profiles within the & 3.6 & 14.3 & 28.6 & 44.6 & 8.9 \\
0 & industry. & & & & \\
& Total & 3.95 & 14.3 & 18.41 & 41.43 & 21.96 \\
\hline
\end{tabular}

1. Note: $S D=$ strongly disagree, $D=$ disagree, $N=$ Neutral, $A=$ agree, $S A=$ strongly agree

The result in Table 4 shows that the overall percentage of $63.39 \%$ of the responses of the respondents indicate that they have positive attitudes to the benefits of CAT tools while only $3.95 \%$ strongly disagreed and $14.3 \%$ disagreed with the statements of benefits of CAT tools. Around $85 \%$ of the participants agreed with (agreed or strongly agreed) that CAT tools increase productivity, using CAT tools makes translators work faster and make translation easier. $75 \%$ of the participants think that the benefits of using CAT tools are apparent to them. $67.9 \%$ of the participants agreed on using CAT tools to improve the quality of their translation, the percentage of this statement is low in comparison to other statements. One unanticipated finding was that of statements No 7, 57.1\% of the participants disagree with that they would lose their work if they could not work with CAT tools furthermore $30.4 \%$ of them were neutral, only $12.5 \%$ agreed on this notion. Around half of the responses of the participants agree with that translator who uses CAT tools get more work and he has a high profile, but around $30.4 \%$ were neutral with this notion. The familiarity of using CAT tools does not play much roles to become an established translator.

Generally speaking, the respondents show a positive attitude towards the benefit of CAT tools. They believe that CAT tools are very fruitful in respect of productivity, facilities offered by these tools, and the advantages of these tools. But they do not show a positive attitude to the effect of CAT tools on their work and getting jobs. They may think that CAT tools do not play a fundamental role in getting better jobs or affect their profiles as established translators.

\subsection{Compatibility of CAT tools}

The following table consists of seven statements; these statements investigate the compatibility of CAT tools. 
Table 5. Compatibility of CAT tools

\begin{tabular}{cllllll}
\hline $\mathrm{N}$ & Statements & $\mathrm{SD}$ & $\mathrm{d}$ & $\mathrm{N}$ & $\mathrm{A}$ & $\mathrm{SA}$ \\
\hline 1 & $\begin{array}{l}\text { Using CAT tools suits my learning/work } \\
\text { style. }\end{array}$ & 1.8 & 5.4 & 23.2 & 51.8 & 17.9 \\
2 & $\begin{array}{l}\text { Using CAT tools completely fits my } \\
\text { current studying/ work situation. }\end{array}$ & 00 & 5.4 & 30.4 & 44.6 & 19.6 \\
3 & $\begin{array}{c}\text { CAT tools are helpful in the area in } \\
\text { which I translate. }\end{array}$ & 1.8 & 3.6 & 21.4 & 51.8 & 21.4 \\
4 & $\quad 3.6$ & 1.8 & 23.2 & 51.8 & 19.6 \\
5 & $\begin{array}{l}\text { CAT tools offer the features I need. } \\
\text { CAT tools do not hinder my creativity as }\end{array}$ & 1.8 & 21.4 & 14.3 & 39.3 & 23.2 \\
$\quad \begin{array}{l}\text { a translator. } \\
\text { CAT tools meet the needs of translation } \\
\text { agencies more than those of the translators. }\end{array}$ & 3.6 & 16.1 & 35.7 & 30.4 & 14.3 \\
$\quad$ I think that CAT tools are affordable. & 8.9 & 41.1 & 16.1 & 19.6 & 14.3 \\
$\quad$ Total & 3.07 & 13.54 & 23.47 & 41.32 & 18.61 \\
\hline
\end{tabular}

The result in Table 5 shows that the overall percentage of $59.93 \%$ of the responses of the respondents indicate that they have positive attitudes to the compatibility of CAT tools while only $3.84 \%$ strongly disagreed and $10.47 \%$ disagreed with the statements of compatibility of CAT tools. They reported that CAT tools suit their careers, and helpful. $23.2 \%$ of the responses indicate that CAT tools hinder translators' creativity; the same percentage informs that CAT tools meet the needs of agencies more than translators' needs. Amazingly, half of the participants believe that CAT tools are not affordable, only $33.9 \%$ of the participants think that CAT tools are affordable. In this section, the neutrality scores the percentage of $(23.47 \%)$, which may indicate that the CAT tools are not much compatible. Generally speaking, around $60 \%$ of the participants believe that CAT tools are compatible, but the problem is the high cost of some CAT tools such as SDL Trados and MemoQ.

\subsection{Ease of use of CAT tools}

The following table consists of seven statements; these statements investigate the ease of use of CAT tools

Table 6. Ease of use of CAT tools

\begin{tabular}{lllllll}
\hline $\mathrm{N}$ & Statements & $\mathrm{SD}$ & $\mathrm{d}$ & $\mathrm{N}$ & $\mathrm{A}$ & $\mathrm{SA}$ \\
\hline 1 & $\begin{array}{l}\text { Overall, I believe that CAT tools are easy to } \\
\text { use. }\end{array}$ & 5.4 & 19.6 & 10.7 & 53.6 & 10.7 \\
2 & It is easy for me to use CAT tools & 1.8 & 14.3 & 17.9 & 46.4 & 19.6 \\
3 & CAT tools are translators friendly. & 00 & 3.6 & 16.1 & 58.9 & 21.4 \\
4 & Using CAT tools facilitate teamwork. & 3.6 & 3.6 & 21.4 & 48.2 & 23.2 \\
5 & CAT tools are complicated & 5.4 & 48.2 & 25.0 & 16.1 & 5.4 \\
6 & I feel confident when I use CAT tools. & 3.6 & 8.9 & 23.2 & 46.4 & 17.9 \\
7 & CAT tools require much training. & 7.1 & 41.1 & 8.9 & 32.1 & 10.7 \\
& Total & 3.84 & 19.9 & 17.6 & 43.1 & 15.55 \\
\hline
\end{tabular}


The result in Table 6 shows that $58.65 \%$ of the participants think that CAT tools are easy to be used in general. $66 \%$ of the respondents believe that it is easy for them to carry out tasks using CAT tools, whereas $80.3 \%$ agree that they are translators-friendly

The majority of the participants (71.4\%) also agree that CAT tools facilitate teamwork. Only $21.5 \%$ of respondents think that CAT tools are complicated. $64.3 \%$ of respondents feel confident when using CAT tools. But 42.7 of their responses indicate that CAT tools require much training.

Generally speaking, the respondents show a positive attitude towards the ease of use of CAT tools. They believe that CAT tools are easy to be trained, they also encourage teamwork, and they raise the confidence of the translators. The participants indicate the necessity of much training.

\subsection{Image of the users of CAT tools}

The following table consists of three statements; these statements investigate the image of the users of CAT tools

Table 7. Image of the users of CAT tools

\begin{tabular}{|c|c|c|c|c|c|c|}
\hline $\mathrm{N}$ & Statements & SD & D & $\mathrm{N}$ & A & SA \\
\hline 1 & $\begin{array}{l}\text { Using CAT tools improve my image within } \\
\text { the organization. }\end{array}$ & 5.4 & 7.1 & 25.0 & 48.2 & 14.3 \\
\hline 2 & $\begin{array}{l}\text { My colleagues in my organization see me as } \\
\text { more valuable because of my use of CAT } \\
\text { tools. }\end{array}$ & 00 & 14.3 & 51.8 & 16.1 & 17.9 \\
\hline 3 & $\begin{array}{l}\text { Translators who use CAT tools have more } \\
\text { prestige than those who do not. }\end{array}$ & 7.1 & 14.3 & 33.9 & 28.6 & 16.1 \\
\hline & Total & 4.16 & 11.9 & 36.89 & 30.95 & 16.1 \\
\hline
\end{tabular}

The result in Table 7 shows that only $47.5 \%$ of the participants believe that CAT tools have such influences on translators' image. $62.5 \%$ of the participants believe that CAT tools improve their image as translators. Only $34 \%$ of the respondents think that CAT tools may play a role to make the users of CAT tools more valuable in the eyes of colleagues. Less than half $(44.7 \%)$ believe that the users of CAT tools have more prestige than non-users. Astonishingly, neutrality scored the highest percentage which may indicate that the participants are not sure about the effect of CAT tools on the image of the translators.

Generally speaking, in comparison to the above three constructs, the responses to this construct show a negative attitude towards the image of the users of CAT tools they believe that CAT tools do not affect the image of the translator whether he uses CAT tools or not. In general, 36.89\% of the responses of the respondents were neutral; it may indicate that they do not feel that using CAT tools affect the image of the users.

The researchers gathered some data through WhatsApp chat with some participants. They indicated that CAT tools are expensive; also CAT tools are difficult to be learned.

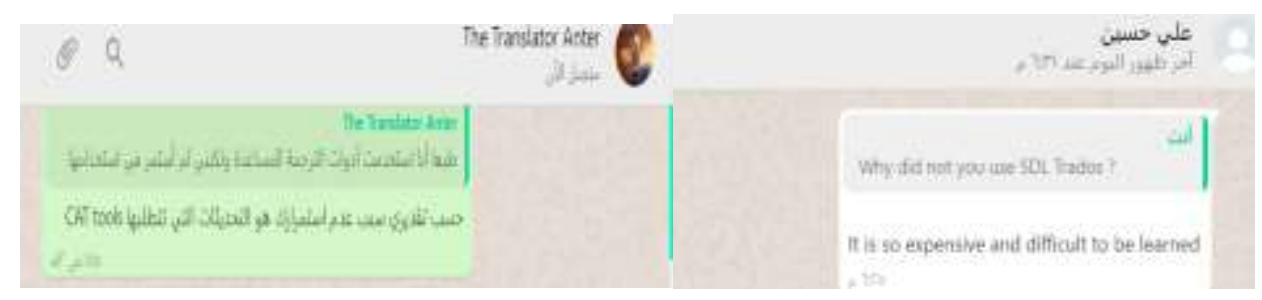


Another translator reported that he was using CAT tools, but he stopped using CAT tools because he is good at typing so he does not bother himself to use any CAT tool.

Table 8. The effect of computer skills

\begin{tabular}{llllll}
\hline & & & & \multicolumn{2}{c}{ 95\% Confidence Interval for Mean } \\
& Mean & Std. Deviation & Std. Error & Lower Bound & Upper Bound \\
\hline Excellent & 3.5360 & .42303 & .08141 & 3.3686 & 3.7033 \\
very good & 3.6378 & .44408 & .08546 & 3.4621 & 3.8134 \\
good & 3.4921 & .37027 & .07126 & 3.3456 & 3.6385 \\
Total & 3.5553 & .41301 & .04589 & 3.4639 & 3.6466 \\
\hline
\end{tabular}

Table 9. ANOVA test

\begin{tabular}{llllll}
\hline & Sum of Squares & df & Mean Square & F & Sig. \\
\hline Between Groups & .302 & 2 & .151 & .882 & .418 \\
Within Groups & 13.345 & 78 & .171 & & \\
Total & 13.646 & 80 & & & \\
\hline
\end{tabular}

The results as shown in Tables 8 and 9 indicate that there is no significant difference between the three groups of participants, the mean of those who have excellent competence in handling computer is 3.53 , while whose very good is 3.63 and for good is 3.49 which indicate that there is no big gap between the three groups. Also, the P-value is 418 which is very large which indicates that there is no significant difference (.418) between the three groups. So the hypothesis is rejected. The results show that computer skill does not play any role in the attitudes of Yemeni professional translators and translation students towards CAT tools. This means the experience, job, age, and computer skills do not play much role in the attitudes of Yemeni professional translators and translation students towards CAT tools. The result of this study is in opposition to the findings of Mahfouz (2018) and Dillon and Fraser (2006). They found the effect of newly graduated students and experiences on CAT tools implementations is fundamental.

\section{Discussion}

The current study aims at investigating the attitudes of professional translators and translation students towards CAT tools in Yemen (a country with low income). The first research question is: Do Yemeni translators and translation students have a positive attitude toward CAT tools and are enthusiastic to implement CAT tools?

The results of the study indicated that Yemeni translators and translation students have a positive attitude toward CAT tools and are enthusiastic to implement CAT tools. The four constructs are analysed; the participants show a high percentage of readiness to implement CAT tools if some issues go in their current- such as financial, technical issues. They show great positive attitudes in general, but they do not believe that CAT tools affect the image of translators if s/he does not use CAT tools. The attitudes of the participants - professional translators and translation students were similar and positive. 
The second research question is Do Yemeni professional translators and translation students who have good knowledge of computer skills have more positive attitudes towards CAT tools than those who do not have good knowledge?

The results of the study indicated that Yemeni professional translators and translation students who have good knowledge in handling computer have more positive attitudes towards CAT tools than the participants who do not have good knowledge of computer skills. They found that computer skill has no significant effect on the attitudes of Yemeni professional translators and translation students towards CAT tools. The results come as in tables 8 and 9.

It becomes clear that there is an agreement among participants on the benefits of using CAT tools (63.39\%). They believe that CAT tools are very fruitful in respect of productivity, facilities offered by these tools, and the advantages of these tools. But they do not show a positive attitude to the effect of CAT tools on their work and getting jobs. The finding may indicate that CAT tools do not play a fundamental role in getting better jobs or affect their profiles as established translators. More than half of the participants state that 'they will not lose their works if they could not work with CAT tools', furthermore $30.4 \%$ were neutral, and this neutrality may prove this notion. Around half of the responses of the participants agree with that translator who uses CAT tools get more work and have high profiles. The familiarity of using CAT tools does not play such a role to become an established translator. The participants also indicate that CAT tools do not require much training. It is worth mentioning that the participants show a positive attitude towards the compatibility of CAT in respect of needs, including their working, their need but they reported that CAT tools meet the needs of translation agencies more than those of the translators. In respect of the affordability of CAT tools, only half of them agreed on the affordability of CAT tools. For the section of the ease of use, only $64.01 \%$ of the participants believe that CAT tools are easy to be used, easy to be trained, and teamwork encouraging, CAT tools raise the confidence of the translators. But the result indicates to the necessity of much training. CAT tools do not affect the image of the translator whether s/he uses CAT tools or not. In general, $36.89 \%$ of the responses of the respondents were neutral; it may indicate that they do not feel that using CAT tools affect the image of the users.

Coming with the hypotheses of the study, the results discussed above prove the first hypothesis which states that. They are highly motivated to use CAT tools. The second hypothesis is not proved, it was rejected, the results show that the profiles of the translators- age, computer skills, experience, do not play a major role to affect the attitude of the participants towards CAT tools.

\section{Conclusions}

Many studies were conducted to explore the attitudes of translators towards CAT tools. They concluded that translators showed positive attitudes towards CAT tools. The present study investigates the attitudes of professional translators and translation students towards CAT tools. It surveyed 56 participants in Yemen. It shows that the participants show a positive attitude towards the benefits, ease of use, compatibility, but they show a negative attitude to the image of CAT tools on translators. The participants ascertain that CAT tools enable teamwork. CAT tools do not hinder the translator's creativity. The results indicate that CAT tools training is much needed. But those participants mentioned that CAT tools meet the demands of agencies more than translators' needs. Only half of the participants consider CAT tools as affordable which means financial issues play a fundamental role. The attitude of professional translators and translation students towards CAT tools was positive in general but in a less percentage in comparison to studies done by Mahfouz (2018) and Dillon and Fraser (2006) which may draw the researchers attention to that the financial and infrastructure affect their attitudes. 


\subsection{Limitation of the study}

The study does have some limitations which should be considered. The limitation of this study is a small and limited sample. The study was conducted in a time where the internet was at its weakest time in Yemen. Many professional translators left Yemen due to the war. The study is the first study in Yemen that deals with CAT tools issues. So the generalization of the study results must be taken with caution. We do not have previous studies to ascertain its result or to compare the results of this study with their results.

Further research can be conducted to investigate the effect of financial and infrastructure aspects on the attitudes of CAT tools uses. Also, some studies can be conducted to check the development in CAT tools implementation in Yemen by Using a similar instrument to cover other and wider samples when the situation getting better. In addition, the authors suggest further studies to investigate the adequacy of the curricular of universities and their influences on teachers' and learners' attitudes toward using technology in translation.

\section{Ethics Committee Approval}

The author(s) confirm(s) that the study does not need ethics committee approval according to the research integrity rules in their country (Date of Confirmation: June 24, 2020).

\section{References}

Ajzen, I. (1989). Attitude structure and behaviour. In A.R. Pratkanis, S.J. Breckler, A.G. Greenwald (Eds.), Attitude structure and function (pp. 241- 274). Lawrence Erlbaum Associates, Hillsdale, NJ,

Al-Jarf, R. (2017). Technology Integration in Translator Training in Saudi Arabia. International Journal of Research in Engineering and Social Sciences, 7(3), 1-7.

Alotaibi, H. M. (2014). Teaching CAT Tools to Translation Students: an Examination of Their Expectations and Attitudes. Arab World English Journal, 3,65-74.

Bundgaard, K. (2017). Translator Attitudes towards Translator-Computer Interaction-Findings from a Workplace Study. HERMES-Journal of Language and Communication in Business, 56, 125-144.

Çetiner, C. (2018). Analysing the attitudes of translation students towards cat (computer-aided translation) tools. Journal of Language and Linguistic Studies, 14(1), 153-161.

Dillon, S., \& Fraser, J. (2006). Translators and TM: An investigation of translators' perceptions of translation memory adoption. Machine Translation, 20(2), 67-79.

Höge, M. (2002). Towards a framework for the evaluation of translators' aids systems (Doctoral dissertation). University of Helsinki.

LeBlanc, M. (2013). Translators on translation memory (TM). Results of an ethnographic study in three translation services and agencies. Translation \& Interpreting, 5(2), 1-13.

McBride, C. (2009). Translation Memory Systems: An analysis of translators' attitudes and opinions (Doctoral dissertation). University of Ottawa, Canada.

Mohammed, O. S. M., Samad, S. S., \& Mahdi, H. S. (2018). A Review of Literature of ComputerAssisted Translation. Language in India, 18(9), 340-359. 
Moore, G. C., \& Benbasat, I. (1991). Development of an instrument to measure the perceptions of adopting an information technology innovation. Information systems research, 2(3), 192-222.

Rico, C. (2001). Reproducible models for CAT tools evaluation: A user-oriented perspective. Translating and the Computer, 23,8-8.

Starlander, M., \& Morado Vazquez, L. (2013). Training translation students to evaluate CAT tools using Eagles: A case study. Proceedings of the $35^{\text {th }}$ Translating and the Computer Conference, London. ASLIB.

\section{Yemen'deki profesyonel çevirmenlerin ve çeviri öğrencilerinin bilgisayar destekli çeviri araçlarına karşı tutumları}

\section{$\ddot{O} \mathbf{z}$}

Çeviri endüstrisi son yıllarda hızlı teknolojik gelişmelere sahne olmuştur. Bu hızlı gelişme, iş yükü için büyük bir talebe bağlanıyor. Çeviri alanında bir bilgisayar kullanmak, hızlı ve doğru çeviri için büyük talep olması nedeniyle çok önemlidir. Çeviri araçları, makine çevirisi yeterliliğinin düşük olması nedeniyle ortaya çıkmıştır. CAT araçları birçok kurum, şirket ve kuruluş için zorunlu hale gelmiştir. CAT araçları verimliliği artırır ve çeviri maliyetlerini en aza indirir. Bu çalışmanın amacı, profesyonel çevirmenlerin ve çeviri öğrencilerinin Yemen'deki CAT araçlarına karşı tutumlarını incelemektir. Bu çalışmanın anketi dört yapıya dağıtılan 27 ifadeden oluşmaktadır. Anketin linki WhatsApp aracılığıyla katılımcılara dağıtıldı. Diğer araç, CAT araçlarıyla ilgili bazı konular hakkında çevrimiçi bir röportajdı. Bu yanıtlar nitelik veri analizi kullanılarak analiz edilmiştir. Araştırmacılar anketi 250 kişiye dağıttı ve katılımcıların geçerli cevapları 56 idi. Analiz, CAT araçlarına karşı olumlu tutumları olduğunu göstermektedir. Çalışmanın sonuçları, profesyonel çevirmenlerin ve çeviri öğrencilerinin olumlu bir tutum sergilediğini göstermektedir. Beklenmedik bir şekilde, katılımcıların profilleri CAT araçlarına karşı tutumlarında herhangi bir rol oynamad.

Anahtar sözcükler: Tutumlar; tercüme; profesyonel çevirmenler; CAT araçları; öğrenciler; Yemen

\section{AUTHOR BIODATA}

Othman Saleh Mahdy Mohammed is a research scholar at Dr. Babasaheb Ambedkar Marathwada University, Department of English. He received his Master degree from Department of English- Sociolinguistics, Hodeidah University, Yemen,. His research areas include translation, translation technologies, Computer Assisted Translation.

Shaikh Suhel Samad is an assistant Professor at Sir Sayyed College Of Arts, Science and Commerce, Dr. Babasaheb Ambedkar Marathwada University, Department of English. He received his PhD from Department of English- literature, Dr. Babasaheb Ambedkar Marathwada University. His research areas include literature and Translation.

Hassan Saleh Mahdi is an assistant Professor at Department of English, College of Arts and Science, Balwarn, University of Bisha, Saudi Arabia, He received his PhD degree from Department of English- ELT, Aligra Muslim University, India. His research areas include Second Language Acquisition (SLA), Computer-assisted language learning (CALL), Mobile-Assisted Language Learning (MALL), and vocabulary acquisition. 